\title{
Virtual Reality: Barter and Restructuring in Russian Industry
}

\author{
By: Gary Krueger and Susan J. Linz
}

William Davidson Working Paper Number 465

April 2002 
Virtual Reality: Barter and Restructuring in Russian Industry

\author{
Gary Krueger \\ Department of Economics \\ Macalester College \\ 310 Carnegie Hall \\ St. Paul, Minnesota 55105 \\ (651) 696-6222 \\ krueger@macalester.edu \\ and \\ Susan J. Linz \\ Department of Economics \\ Michigan State University \\ 101 Marshall Hall \\ East Lansing, Michigan 48824 \\ (517) 353-7280 \\ linz@msu.edu
}

November 2001

revised April 2002

Prepared for presentation at AAASS meetings, Washington D.C., 15-18 November 2001. Linz acknowledges financial support for data collection provided by a short-term travel grant from the International Research and Exchanges Board, with funds provided by the U.S. Department of State (Title VIII) and the National Endowment for the Humanities. Funding provided to Linz by the National Science Foundation, under the auspices of the Women in International Scientific Collaboration program, was also invaluable in the successful completion of this data collection. 


\title{
William Davidson Institute Working Paper 465
}

Virtual Reality: Barter and Restructuring in Russian Industry

\begin{abstract}
A general consensus in the transition economies literature links the existence of enterprise restructuring with the pace of the transition process and the potential for economic growth. The existing literature is less clear, however, about whether the lack of economic growth is caused by the lack of enterprise restructuring. Complicating the debate in Russia is the confusion regarding the role of barter transactions in enterprise restructuring. Much of the confusion is generated by proponents of a "virtual economy" interpretation of how the Russian economy and Russian enterprise managers operate. This paper dispels much of the confusion about the existence of enterprise restructuring and the corresponding role of barter by demonstrating why the virtual economy model fails to accurately depict economic actions or outcomes in Russia. We develop the argument that barter is closely related to an absence of liquidity in the Russian economy, using both macro-level and micro-level data to document the consequences of "structural illiquidity." Our results are unambiguous: both the incidence and volume of barter transactions are inversely related to liquidity. We conclude that analyses using barter transactions as evidence of the lack of enterprise restructuring in Russia stem from: (1) the lack of clear consensus about what constitutes enterprise restructuring in transition economies and how it varies with the stage of the transition process; (2) errant assumptions about managers' objective functions; (3) the relative mix of formal and informal restructuring mechanisms; (4) the lack of attention to industry variation and, within industry, to managerial characteristics; and (5) the Texan complex (if it ain't big, it ain't ...) which causes analysts to ignore changes in enterprise operations unless they occur on a grandiose scale.
\end{abstract}

Keywords: Russia, barter, restructuring, transition

JEL Classification: C22, C23, E5, P2 


\section{William Davidson Institute Working Paper 465}

\section{Virtual Reality: Barter and Restructuring in Russian Industry}

\section{Introduction}

Almost three years of positive economic growth following the financial collapse in 1998 have failed to dispel widespread pessimism concerning Russia's transition to a market economy. Although the most recent reports from Russia are far more positive than they have been throughout the ten years of transition ${ }^{1}-$ investment growth rather than increasing consumer demand is driving the expansion, for example - each positive assessment of Russia's economic performance is matched by an equal number of pessimistic reports. ${ }^{2}$ This is hardly surprising, given the scope of change required to establish a market economy in Russia and the uneven pace of development across various economic, political, and social dimensions. However, while articles in the popular press are now more optimistic concerning the relative success of Russia's transition to a market-oriented economy, current scholarly research on the Russian economy, especially research which focuses on the performance of domestic industry, tends to be decidedly negative concerning Russia's long term economic prospects for sustained development. ${ }^{3}$ The negativism stems in large part from perceptions that Russian manufacturing enterprises are not actively restructuring their

\footnotetext{
${ }^{1}$ According to Goskomstat (2000, 2001), Russia achieved GDP growth of 5.4\% (3.2\%) in 1999, 8.3\% (5.6\%) in 2000; estimates of GDP growth in 2001 continue the positive trend: Russia's Ministry of Economy and Trade predicts $4 \%$ GDP growth in 2001. The World Bank estimates Russia's GDP growth at 5\% in 2001.

${ }^{2}$ See, for example, Anders Aslund, “Think Again - Some Common Misconceptions about Russia,” (2001, pp. 13-15) and Peter Reddaway, "Market Bolshevism Harmed Russia," (pp. 16-19) in Transition Newsletter, vol 12, no 3 (World Bank/William Davidson Institute); see also: "At Economic Forum, Foreign Investors Show Some Confidence in Russia’s Initial Reforms," Wall Street Journal, 31 October 2001, and “Russian Revival,” Financial Times, 30 October 2001.

${ }^{3}$ In addition to western analysts, Broadman (2000), Desai and Idson (2000), Dyker (2000), Ericson (1999), Ickes and Gaddy (1998), and Millar (2000), for example, a number of Russian researchers express skepticism about future growth potential. See, for example, Kleiner (2001), Pinto, Debrentsov and Morozov (2000), Polonsky and Aivazian (2000). Yevgeny Gavrilenko, director of Russia's Economic Analysis Bureau, has on numerous occasions over the past year supported the proposition that Russia's economic (industrial) growth cannot be sustained without the immediate implementation of additional structural and institutional reforms (paper presented at AAASS meetings, November 2000; paper published in Voprosy ekonomiki, 2001; quoted in Transition Newsletter (September 2001, p. 18).
} 


\section{William Davidson Institute Working Paper 465}

operations. ${ }^{4}$ Evidence of the lack of restructuring is offered in the form of the volume of barter and other non-monetary forms of payment made by former state-owned firms in Russia (see Table 1), as well as by the persistence of wage and tax arrears across most branches of Russian industry. ${ }^{5}$

This paper addresses two questions that remain unresolved in the literature: (1) are Russian enterprises actively restructuring? and (2) what role does barter play - is barter an alternative to enterprise restructuring or does barter facilitate restructuring?

Why does it matter if Russian manufacturing firms are restructuring? A general consensus in the transition economies literature links the existence of enterprise restructuring with the pace of the transition process and the potential for economic growth. The extensive literature which has emerged in the past decade provides a multitude of quantitative and qualitative measures of enterprise restructuring in Russia and other transition economies. ${ }^{6}$ The existing literature is less clear, however, about whether the lack of economic growth is caused by the lack of enterprise restructuring. Ickes and Ericson (1999) categorize the literature on poor economic performance in Russia into two schools of thought: those that view poor economic performance as the consequence of "bad policy" and those who focus on "bad structure." While the authors acknowledge the policy mistakes of the Yeltsin era, they consider structural defects as the primary, and more serious, problem to be addressed by analysts and policy makers. Collectively, they refer to

\footnotetext{
${ }^{4}$ The importance of enterprise restructuring in Russia's transition process was underscored by numerous studies documenting the technological backwardness of Soviet industry (Amann and Cooper 1986, Berliner 1976, Leary and Thornton 1989, Linz 1993, Thornton and Linz 1988), as well as by the general recognition that location and productmix decisions in the Soviet centrally planned economy were politically motivated (firms located in regions to reward local political officials or to avoid invasion), with little regard to natural economic advantage (proximity to natural resources, for example) (Frydman and Rapaczynski 1997, Gregory and Stuart 1986, Krueger 1993, Linz 1988).

${ }^{5}$ Pinto et al (2000) are not alone in their conclusions that "virtual absence of serious enterprise restructuring" in Russia is driven by the "persistence of ... soft budget constraints for enterprises" (p. 298); that is, a firm's ability to acquire energy and other inputs without full payment is taken as prima facie evidence of the lack of restructuring. Hendley et al (1997) argue that barter allows firms to sustain socialist production patterns and thus refrain from restructuring.

${ }^{6}$ Much of this literature is summarized in Djankov and Murrell (2000), Gonchar and Wulf (1998), Linz and Krueger (1998), and Sedaitis (2000).
} 


\section{William Davidson Institute Working Paper 465}

these distortions, most of which were inherited as part of the Soviet legacy, as contributing to Russia's “virtual economy" (Gaddy and Ickes 1998).

Fundamental to the "virtual economy" hypothesis (VEH) is the assumption that the primary objective of enterprise managers is to avoid serious restructuring. The argument that managers seek to avoid restructuring is based on the assumption that the primary asset which "red executives" possessed was their "network capital." That is, managers' idiosyncratic knowledge of contacts in the power hierarchy and/or the supply chain allowed them to "prosper" under the old system. Assuming that this specific knowledge is managers' primary asset, understandably, managers are reluctant to devalue it by restructuring the operations or production assortment of their firms. Restructuring, in the "virtual economy" model, is avoided by artificially inflating the balance sheets of poorly performing (value-subtracting) firms, shielding them from bankruptcy and other pressures to change their operations or production assortment (Gaddy and Ickes 1998).

Proponents of the "virtual economy" thesis argue that Russian firms engage in economy-wide deception that "creates" value where none exists in reality. ${ }^{8}$ The instruments through which this deception is effected include widespread use of barter and other quasi-money instruments of exchange, and an apparently permanent level of arrears in payments to workers and suppliers, as well as to federal and local tax authorities. Proponents of the "virtual economy" thesis explain the existence of barter, payment arrears, and other forms

\footnotetext{
${ }^{7}$ Granick (1954) coined this phrase to describe the formal and informal behavior of Soviet managers, in contrast to behavior of their counterparts in market economies.

${ }^{8}$ Millar (1999) uses a national income accounting framework to demonstrate why this cannot happen.
} 


\section{William Davidson Institute Working Paper 465}

of quasi-money by the underlying structural micro-foundations of the Russian economy, and not the consequence of "bad policies" - for example, excessively tight monetary policy leading to low levels of liquidity in the non-financial sector.

In this paper we present an alternative explanation: managers of formerly state-owned firms do consciously seek to restructure their firms and develop normally, but they are fundamentally constrained in their restructuring abilities by low levels of liquidity in the economy. Support for this proposition is found in the response patterns of Russian managers to questions which focus on the desirability and possibility of avoiding non-monetary transactions. The Institute for the Economy in Transition (IET) in Moscow surveyed over one thousand Russian manufacturing firms in 1999 and 2000, asking whether they would like to and whether they could avoid non-monetary transactions. As seen in Table 2, more than $90 \%$ of the firms in the electric energy, ferrous metallurgy, chemicals, engineering (machine tools and instrument making, for example), construction materials and food industries responded affirmatively in 1999 to the desirability of avoiding non-monetary transactions. A similar response pattern holds for the following year. These data suggest that barter and other non-monetary transactions are imposed by circumstance. Moreover, when asked whether they could avoid such transactions, in all but food processing, less than 50 percent of the manufacturing firms participating in the survey reported being able to do so. That a significant share of firms engage in barter transactions, despite reporting themselves as able to avoid them, indicates that barter and other non-monetary transactions facilitate or enhance the firms' operations. ${ }^{9}$

In Russia's liquidity-constrained environment, barter and other non-monetary payments perform an important function in the transition process: until capital markets develop and contract enforcement is assured, barter and other non-monetary payments permit the continued survival of potentially viable firms. ${ }^{10}$

\footnotetext{
${ }^{9}$ Linz and Noguera (2002) demonstrate that barter enables a firm to produce a higher level of output than would be possible if transactions are restricted to cash.

${ }^{10}$ For further discussion, see Brana and Maurel (2000), Desai and Goldberg (2000), and Yakovlev (2000).
} 


\section{William Davidson Institute Working Paper 465}

We do not suggest that the travails of Russia's economic transition have been simply the result of bad (macro) policies. Rather, we argue that "structural illiquidity"11 in the Russian economy is symptomatic of a deeply-rooted structural problem in the financial sector, not in the restructuring behavior of Russian managers. In our analysis, the fundamental problem lies with the Russian banking sector's unwillingness to lend to Russian industry at competitive interest rates for periods longer than a few months' duration. Failure to address this problem impedes the nascent progress of Russia's transition to a fully-functioning market economy.

\section{Empirical Challenges to the Virtual Economy Hypothesis}

Despite the compelling argument put forth by proponents of the "virtual economy" hypothesis (VEH), we find the VEH incomplete in explaining several phenomena of the Russian economy. One empirical prediction of the assumption that managers seek to preserve their network capital via the use of quasi-money

is that the overall level of quasi-money in the economy would remain relatively stable through time. ${ }^{12}$ Monthly data on the incidence of barter in Russia's transition economy (see Figure 1) indicate a high variance over time in the use of quasi-money: barter accounted for a low level of total transactions in the early 1990s, peaked in 1998 and began to decrease after the 1998 financial collapse. We examine alternative explanations for this observed pattern of barter transactions, identifying two actors that account for a large fraction of the variance: the real value of Russia's currency, the ruble, and the world market price of oil.

\footnotetext{
${ }^{11}$ We acknowledge Vladimir Popov for suggesting this phrase.

12 The terms "barter" and "quasi-money" are used interchangeably. The literature and official data sources frequently combine all non-monetary transactions, including barter, veksels, and zachety because all are less liquid than cash, all impose extra transactions costs, and all are associated with an uncertain rate of return.
} 


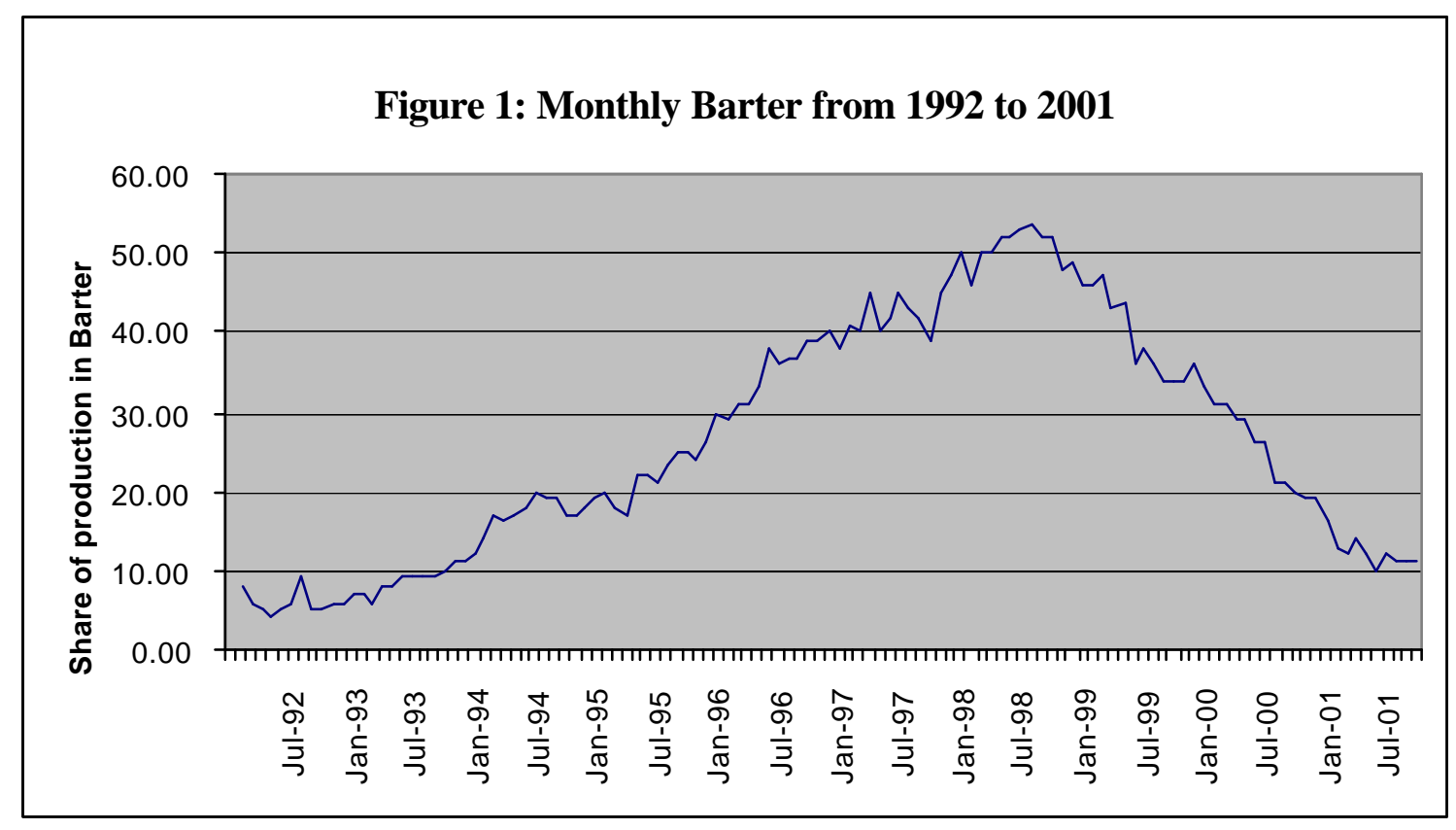

Source: Russian Economic Barometer and Institute for Economy in Transition (IET).13

Second, if the "virtual economy" hypothesis is correct and managers voluntarily choose barter over other means of transacting, then we should see the incidence of quasi-money more or less uniformly distributed across different industries. ${ }^{14}$ In this paper we show that barter is concentrated in industries which are removed from the final customer (machine building and other heavy industry branches); industries which consequently have less direct access to cash. The exception to this rule is the metals and non-ferrous metals sectors which export a considerable fraction of their total production for hard currency and thus have relatively good access to liquid assets. Given Russia's under-developed banking system, firms without direct access to cash have resorted to barter and other non-monetary transactions to sustain themselves. The

\footnotetext{
${ }^{13}$ Data in Figure 1 are from Russian Economic Barometer and were provided by John Littwak from OECD and were updated by data generously provided by Sergei Tsuklo at IET. Data in figure 2 were provided by IET. Both sources use a survey of several hundred Russian enterprises to generate their results.

${ }^{14}$ Commander and Mumssen (1998), based on survey of over 300 enterprises, provide substantial evidence suggesting that barter is the result of lack of liquidity in the system, and is not preferred by managers as would be expected under the "virtual economy" hypothesis. Linz and Krueger (1998, table 8) use survey data collected from enterprises located in several regions in Russia between 1995 and 1998 to demonstrate the significant variation in the use of barter by industry.
} 


\section{William Davidson Institute Working Paper 465}

persistence of informal (non-market or non-monetary) transactions supports the illiquidity hypothesis $;^{15}$ that is, barter transactions and other forms of quasi-money are employed when cash is difficult to obtain.

Third, we challenge not only the assumption that managers seek to avoid restructuring, but also its related counterpart - that the "restructuring avoidance" objective is widely shared among Russian managers. Our findings indicate that when managers are unconstrained in terms of access to cash, they generally respond aggressively to whatever opportunities are present; when liquidity constraints are binding, the scope of restructuring activities is restricted. Moreover, we find that the magnitude of the restructuring response, holding access to cash constant, depends in large part on managerial characteristics.

The remainder of this paper is divided into three sections. Section 2 develops the argument that barter and the use of non-monetary instruments is closely related to an absence of liquidity. Section 3 uses firm-level data to show that enterprise use of barter varies widely across industries and is associated with a firm's access to direct sources of cash. We view this result as important in that it indicates that Russian managers are not, generally speaking, averse to restructuring per se, they just need the opportunity to do so and when given the opportunity, like most self-interested people, they generally take it. We also show that, despite anecdotes to the contrary, barter prices are not outrageously distorted relative to cash prices, suggesting that barter and quasi-money are not being used by managers as a means of deception, but is the result of limited access to liquidity. Section 4 concludes the paper.

\section{Explaining Variations in the Aggregate Level of Barter}

We start from the premise that the choice of mechanism to complete a particular transaction is analogous to choosing a financial asset. From this perspective, barter transactions fare rather poorly vis-a-vis

\footnotetext{
${ }^{15}$ In a detailed critique of the "virtual economy" concept, Millar (1999, p. 13) offers a variety of explanations for why the illiquidity environment intensified prior to the financial crisis of 1998 as firms hoarded cash: (1) cash was used to speculate against the exchange rate, (2) cash was used to purchase interest-bearing debt instruments from the state budget (GKOs, OFZs), (3) cash was invested in foreign securities and/or simply (4) held in foreign exchange as a hedge against inflation, (5) cash was used to purchase state property being auctioned by the state to pay its bills, (6) cash was used by "new Russians" to consume conspicuously.
} 


\section{William Davidson Institute Working Paper 465}

more liquid alternatives: (1) barter transactions are more costly than cash transactions to conduct; (2) barter transactions have a highly uncertain return because enforcement of barter agreements depends upon trust and a whole chain of associated transactions in order to obtain the anticipated return. When set against the advantages of cash, barter appears to be a strictly inferior asset: (1) cash transactions provide low risk and a high degree of certainty with respect to return, and (2) an individual cash transaction is less costly to complete. Moreover, not only have the advantages of access to cash in Russia's transition economy been substantial (Millar 1999), cash retains significant tax avoidance advantages, although perhaps not fully commensurate with barter in this dimension. In most dimensions, a cash transaction would be strictly preferred to a barter transaction. This observation is supported by the response patterns of Russian managers (see Table 2).

Do Russian managers choose barter transactions to preserve the network capital which they inherited from the Soviet era? If so, then we should see the level of barter in the economy at the beginning of the transition to be relatively high and perhaps to diminish overtime. Figure 1 graphs the share of barter in Russian industry from 1992 to August of 2001. Clearly, the share of barter in industrial production varies considerably over time, from a very modest share near $10 \%$ in the early 1990 s, to over half of total production in 1997-1998, before declining to 1992 levels by early 2001.

If Russian enterprise managers choose barter to maintain existing relationships, as the VEH claims, we would expect to see the share of barter begin at a high level in 1992, when the vast majority of managers were Soviet era holdovers. Replacement of these managers over time, through natural attrition or more active governance initiatives, would cause the share of barter sales to diminish. The pattern illustrated in Figure 1, based on the monthly responses of over 900 Russian enterprise managers in all branches of industry, are clearly at odds with this prediction. Only after the financial crisis of 1998 do we find evidence of the decline in the share of barter transactions.

In addition to reporting the share of barter transactions each month, firms which participate in the 


\section{William Davidson Institute Working Paper 465}

IET surveys are asked about past trends and expected trends in the share of barter transactions. As seen in

Table 3, the percentage of manufacturing firms reporting an increase in barter transactions dropped from 12-

$13 \%$ in the spring of 1999 , to $7 \%$ at the end of the year. More than double that percentage consistently

reported a decline in the volume of barter transactions. This pattern is repeated in 2000 and 2001. Moreover,

after 1999, there is a significant decline in the percentage of managers expecting barter transactions to

increase. The fact that 50-60\% of the manufacturing firms participating in the monthly surveys neither experienced nor expected a change in the volume of barter transactions may be interpreted as evidence of a structural problem in the Russian economy which businesses do not think will be fixed in the short term. Consequently, they have come to view barter transactions as "normal."16 Alternatively, it may reflect firms' perceptions of the instability of the economy: firms experiencing a decline in barter transactions do not expect it to last - the "current down" is greater than the "expected down" in almost every month.

A second element which the VEH does not address, and would have difficulty explaining, is the fact that the incidence of barter varies significantly across major industrial branch. Both Table 1 and Figure 2, based on survey data provided by the Institute for the Economy in Transition (IET), illustrate the incidence of barter across major industrial branches of Russian industry from 1996 to 2001 . The data in Figure 2 are averaged over the five-year period.

\footnotetext{
${ }^{16}$ In four surveys of over 950 Russian manufacturing firms conducted in 2001 by the Institute of the Economy in Transition, managers were asked to respond to the question: Do you consider that in volume terms barter transactions are currently above normal, below normal or normal? In each case (January, April, July, and October), $40 \%$ of the respondents selected "normal;" about $10 \%$ viewed the current volume of barter transactions as "below normal."
} 


\section{William Davidson Institute Working Paper 465}

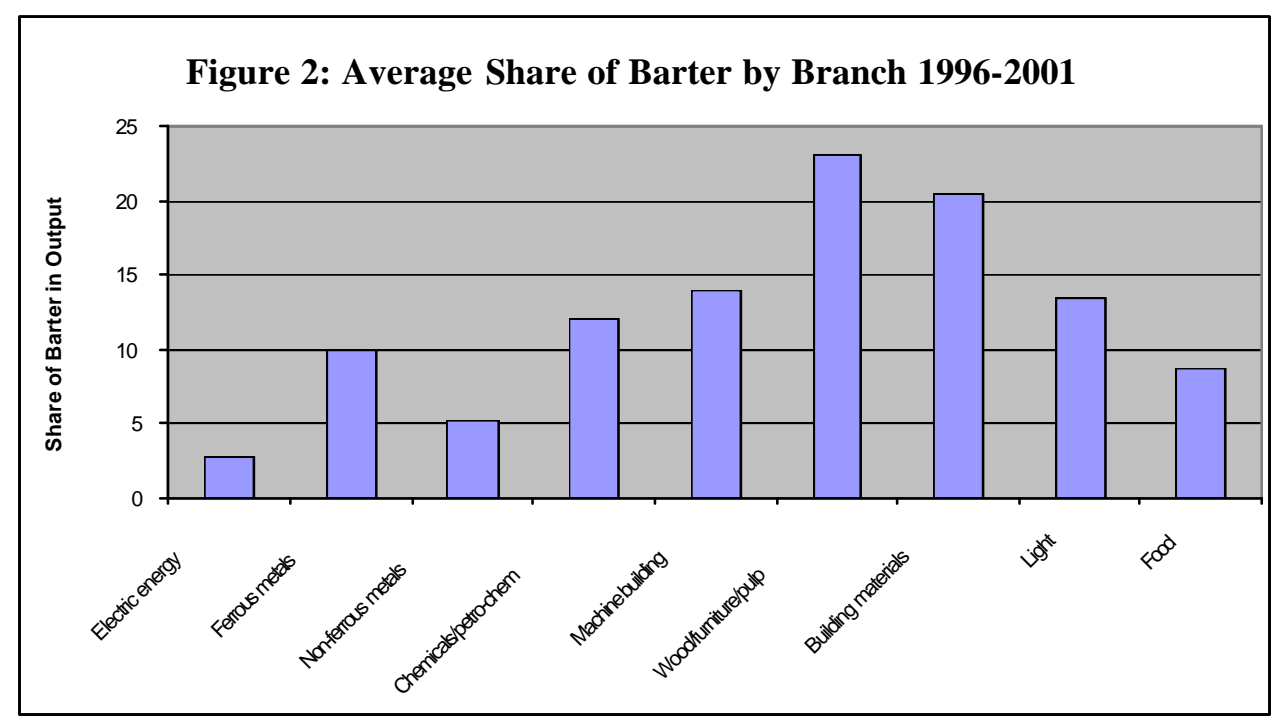

Source: Institute for Economy in Transition (IET)

Evident in Figure 2 is the low share of barter in the electric energy, metals and food processing industries. Chemicals, machinery, wood products, building materials and light industry all report a significantly higher incidence of barter over the five year period. Using the 51 observations from 1996 to 2001, we regress the share of barter in total transactions, that is, the incidence of barter trades, on two independent variables: a dummy variable to account for the 1998 financial crisis and a dummy variable that equals 1 if the branch was food, metals or non-ferrous metals. This specification explains 68 percent of the variation in the incidence of barter and predicts an 8.5 percent lower share of barter for firms in the food processing, metals or non-ferrous metals industries $(\mathrm{t}$-statistic $=-2.67) .{ }^{17}$ These results are consistent with in-depth interviews we conducted with hundreds of Russian managers over the past seven years: industry variation in the incidence of barter transactions coincides with access to cash and other liquid assets in the economy. While the VEH makes no clear prediction concerning the pattern of barter by industrial branch, these data support the hypothesis that barter is more prevalent when firms are liquidity constrained. ${ }^{18}$

\footnotetext{
17 The probability that this coefficient is zero is approximately $1 \%$.

${ }^{18}$ See Krueger (1995, 2002 forthcoming), Linz and Krueger (1998).
} 


\section{William Davidson Institute Working Paper 465}

If illiquidity is the primary cause of barter in Russia, then we should find a significant correlation between the incidence of barter and changes in the overall level of liquidity in the economy. One common measure of liquidity is the ratio of claims of the banking sector on the non-financial sector relative to GDP. ${ }^{19}$ While this ratio is widely regarded as an appropriate indicator of liquidity, the requisite Russian data are available only on a quarterly basis, which severely reduces the number of observations for our analysis. Nonetheless, using data from the IMF International Financial Statistics, we calculated the ratio of claims on the non-financial sector to GDP for Russia from 1993 to the first quarter of 2001. After converting the monthly barter data to quarterly data, we examined the relationship between the liquidity measure and barter incidence.

We hypothesize that the responsiveness of barter to liquidity operates with a lag. ${ }^{20}$ We use regression analysis to estimate the quarterly incidence of barter as a function of our liquidity measure, the relative share of credit available to manufacturing firms (see Figure 3). Our results indicate that the optimal explanatory power of liquidity occurs at a lag of 2-2.5 years (8-10 quarters). Using a lag of 8 quarters, the univariate regression explains approximately 50 percent of the variation in the incidence of barter (measured quarterly); each 1 percent increase in liquidity is estimated to reduce barter by approximately 4.5 percent. $^{21}$

\footnotetext{
${ }^{19}$ See the OECD 1997 Report on the Russian Federation which provides a comparison of liquidity among several transition economies.

${ }^{20}$ The assumption of a lag coincides with observed monetary phenomena in market economies, where changes in liquidity are only evident after several months. In the Russian economy, where financial and other markets are less developed, the lag is likely to be longer than in a developed market economy. Our reasoning for the lag is based in large part on the realities associated with production and contract agreements in Russia: managers make deals today for delivery in the future (3-6 months, for example); liquidity conditions today govern the actual (future) transaction. We employ a moving average to filter out "noise" in the liquidity conditions because we think that managers do not respond to monthly fluctuations in liquidity if they do not think the condition will persist. The moving average captures the longer run (more persistent) signal of the liquidity conditions in the economy, and it is this signal that we believe managers utilize in their decisions.

${ }^{21}$ The $t$-statistic on this coefficient estimate is -4.5 , with a sample size of 22 observations. It should be noted that serial correlation is a problem in this regression, as are issues of stationarity in the quarterly barter series. Moreover, at this lag length the number of observations falls to 20. Fairly robust results are obtained when liquidity is lagged by anything in excess of 7 quarters, while almost no explanatory power is obtained at lags less than 6 quarters.
} 


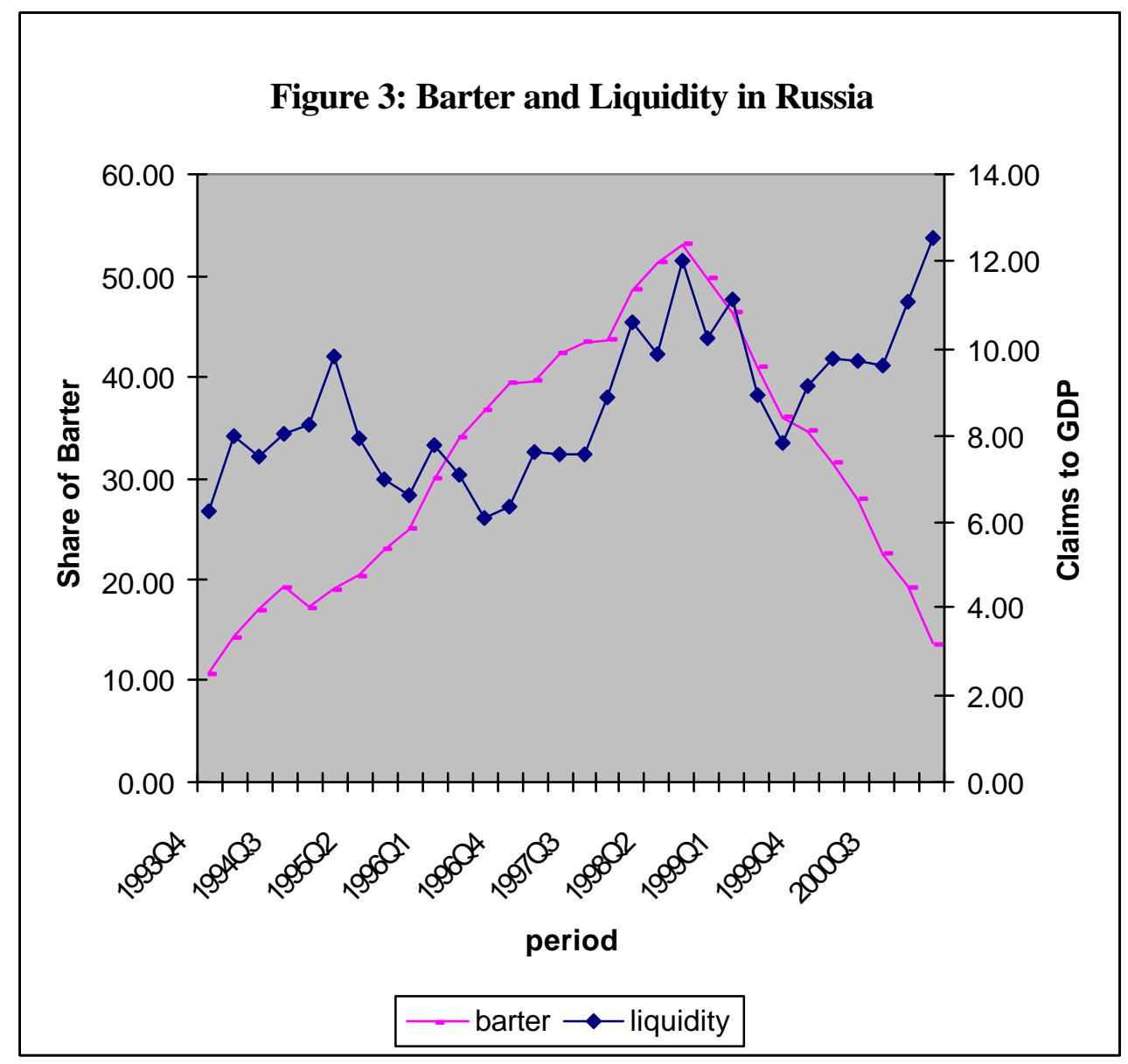

While the hypothesis that barter is the result of low levels of liquidity is supported by these results, the sample size is small and the dependent variable may be non-stationary. Our second measure of liquidity is the real effective exchange rate, that is, the ruble-dollar exchange rate adjusted for inflation in Russia. Exchange rate data are reported weekly. Constructing a monthly exchange rate average allows us to utilize the monthly barter data, thus increasing the number of observations available for our analysis by a factor of four. The real effective exchange rate should mirror the level of liquidity in the economy, although the coefficient estimate will be opposite in sign relative to credit to the non-financial sector. ${ }^{22}$ Initial regressions using the real effective exchange rate averaged over 16 months as the independent variable explained roughly

\footnotetext{
${ }^{22}$ High rates coincide with a "shortage" of currency; low rates coincide with a "surplus" of currency.
} 


\section{William Davidson Institute Working Paper 465}

65 percent of the variation in monthly barter. ${ }^{23}$ Although this is an acceptable level of explanatory power from a univariate regression, the model tended to significantly over-predict barter in the post-crisis period.

We hypothesized that the over-prediction was likely caused by the dramatic increase in the world market price of oil after 1999, which in turn caused an appreciation in the exchange rate while simultaneously providing liquidity to the economy through increased government revenues. ${ }^{24}$ When we included the monthly oil price in the regression, the explanatory power rose to 83 percent, substantially reducing the prediction error after 1999 (see Figure 4). Moreover, the estimated coefficients on the exchange rate and oil price variables are significant and have the correct sign. ${ }^{25}$ In sum, our finding is that the incidence of barter is inversely related to liquidity, regardless of the liquidity measure used.

\footnotetext{
${ }^{23}$ The real effective exchange rate in Russia has a very high month to month variance, especially in the earlyyears of the transition process. In order to eliminate this high variance, a moving average was utilized. We found that a 16month moving average provided the best explanatory power while still preserving sufficient degrees of freedom.

${ }^{24}$ Taxes on oil exports accounts for as much as $30 \%$ of the federal tax revenues, and accounts for a substantial share of the hard currency earnings available to central authorities, given the regulation which requires exporting firms to give $50 \%$ of their dollar earnings to central authorities in exchange for rubles.

${ }^{25}$ A low Durbin-Watson statistic indicates a high level of serial correlation in the errors. We re-estimated the basic relationship using E-Views iterative FGLS estimation for first-order serial correlation, as well as for second-order serial correction results. Despite changes in the estimation technique, the estimated coefficients remain stable. Unlike the quarterly data, tests for unit roots in the residuals are rejected, indicating that the series are co-integrated in the Granger-Engle sense. The ADF statistic on the residuals with no intercept or trend below -5 , well below the rejection value.
} 
Figure 4: Actual and Fitted Barter

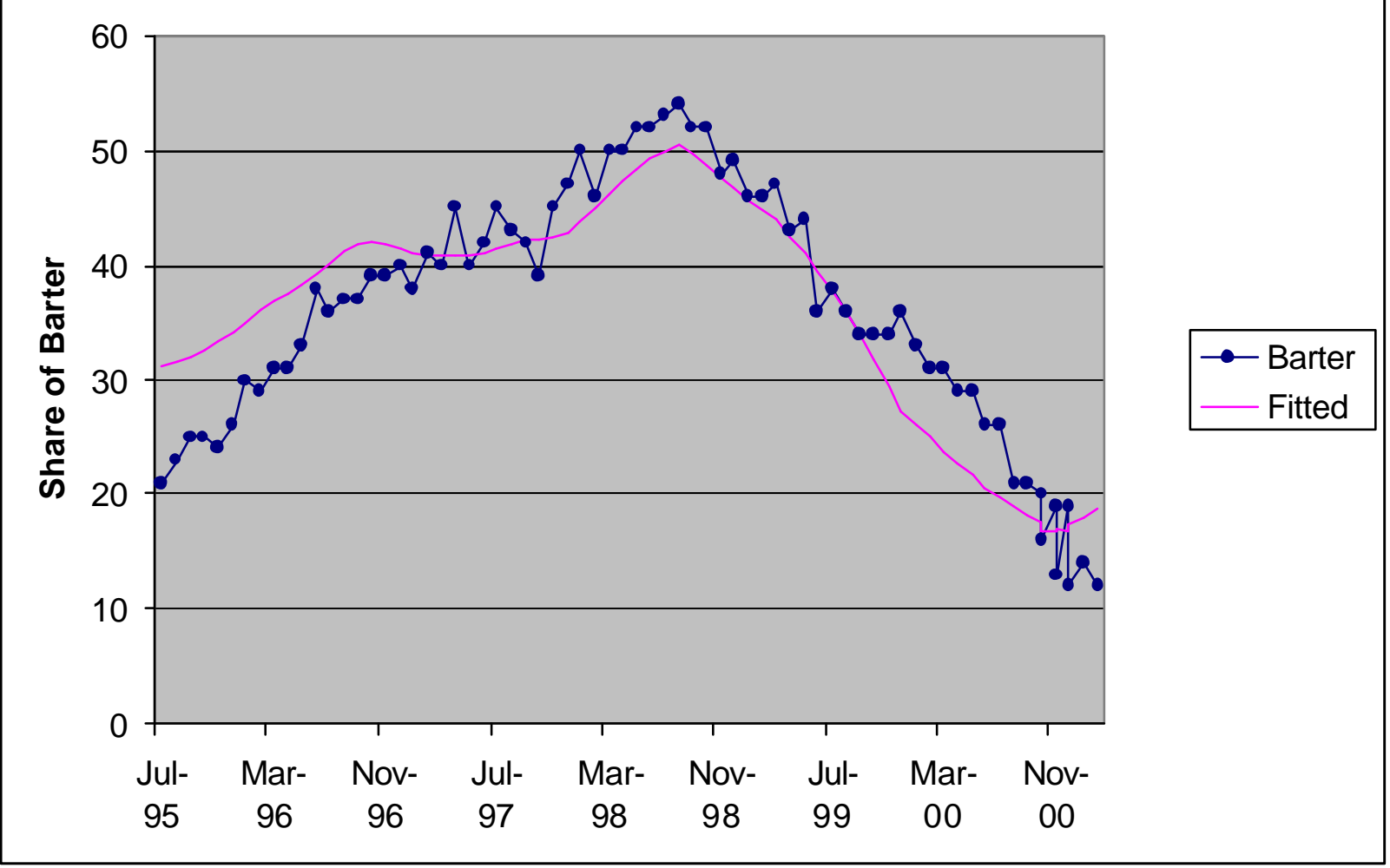

The most recent variation of the VEH argues that the central issue is neither the incidence nor the volume of barter transactions among Russian manufacturing firms, but rather the cross subsidization from the energy sector to the value-subtracting sector, that is, Russian industry (Gaddy and Ickes 2000). In this iteration of the VEH, the authors argue that we should not be surprised at the decrease in barter as measured in rubles, because the devaluation of the exchange rate (from 7-8 rubles per dollar to 25-30 rubles per dollar) increased the size of the export sector relative to the rest of the (barter and domestic cash) economy by approximately 15- 20 percent. Additionally, the ruble devaluation also resulted in growth in GDP measured in inflation-adjusted rubles.

While Gaddy and Ickes correctly approximate the increase in the export sector relative to the rest of the economy, their approach vastly under-predicts the decline in the incidence of barter transactions in the economy. In their example, the devaluation results in a 20 percent decline in the incidence of barter, leading 


\section{William Davidson Institute Working Paper 465}

to an overall level of barter at 40 percent of GDP, down from the 50 percent peak in mid-1998. Actual data (see Table 1 and Figure 1) indicate a much larger decline: barter transactions fall to roughly 10 percent. Moreover, if devaluation is the only force driving Russia's current expansion we should see a one-time positive shock to GDP (given an appropriate adjustment period), and then a return to the former trend; essentially, zero real growth. The actual situation is much different: real GDP growth in Russia is apparent for three years after the August 1998 devaluation. ${ }^{26}$ These two outcomes - a significantly larger decline in barter and the apparently sustained growth in the economy - suggest that the VEH's underlying assumptions of managerial behavior, particularly the assumption that firms actively seek to avoid restructuring, are no longer correct (if, in fact, they ever were).

The final component of our macro-level analysis focuses on the nature of the cross-subsidization from the energy sector to the rest of the economy. A recent report by the research office of Russia's AlphaBank documents the bulk of subsidies from Gazprom and UES going to the communal housing sector, not industry. Their data indicate that industry receives less than half the subsidy allocated to the housing. ${ }^{27}$ Indeed, the authors conclude that financing the communal housing sector, not subsidizing industry, constitutes the major stumbling block to reform.

\footnotetext{
${ }^{26}$ The September 2001 issue of Russian Economic Trends indicates real growth in GDP throughout the year 2000 and continuation into the first quarter of 2001. The Economist, 27 October 2001 (p. 102), indicates a 5\% increase in GDP in the second quarter of 2001, over the previous year.

27 Natalia Orlova and Andrei Roudenko, "Cross Subsidization: Roadblock to Reform,” Alpha-Bank Research Department (29 June 2001). They calculate a subsidy of $\$ 3.6$ billion to industry and a subsidy of $\$ 8.6$ billion to the communal housing sector. Using World Bank data (http://ww.worldbank.org/data/wdi2000.pdf), industry accounts for 38\% of GDP in 1999, where GDP is estimated at $\$ 401.442$ billion (U.S.). Alpha-Bank shows a subsidy of $\$ 1.5$ billion (electric) and $\$ 2.1$ billion (gas) which works out to $2.3 \%$ of total sales.
} 


\section{William Davidson Institute Working Paper 465}

In contrast to the $\mathrm{VEH}$, we find considerable and compelling evidence at the macro level in support of the liquidity hypothesis as the primary cause of barter in Russia. Additionally, we find barter varies significantly at the industry level according to differentials in liquidity. In the next section, we utilize firmlevel data to investigate in greater detail the relative importance of liquidity constraints in explaining barter transactions among Russian firms.

\section{Barter transactions among Russian firms: descriptive and empirical analysis}

Explanations for the widespread incidence of barter transactions among Russian manufacturing firms fall into two categories: choice and circumstance. Those viewing barter transactions as a choice made by managers focus on the way in which barter transactions can be used to avoid taxes, divert profits, conserve cash, price discriminate, and delay restructuring (Gaddy and Ickes 1998, Guriev and Ickes 1999, Guriev and Kvassov 2001, Woodruff 1999). Those viewing barter transactions as forced upon the firm by circumstances associated with the transition focus on: (1) the economic disorganization caused by the dismantling of the planned economy, the collapse of production chains and disruptions in supplier-customer relationships, as well as by the lack of an appropriate legal system (Blanchard and Kremer 1997, Carlin et al 2000, Ellingsen 1998, Hendley et al 1998, Marin and Schnitzer 1999, Polterovich 1997); (2) liquidity constraints caused by high inflation, delayed government payments for goods delivered and services rendered, and an underdeveloped banking structure (Commander and Mumssen 1998, Brana and Maurel 1999, Guriev, Makarov and Maurel 2000, Hendley et al 1998, Linz and Krueger 1998); and (3) the Soviet legacy of price formation, ${ }^{28}$ profit confiscation, and reciprocal obligations (Gaddy and Ickes 1998, Makarov

\footnotetext{
${ }^{28}$ Despite price liberalization in January 1992, tax authorities continued to use cost-plus pricing in their determination of the tax obligations of firms. Firms had no incentive to sell at a price lower than the price specified by tax authorities, because the tax obligation was based on the cost-plus price. Given the high proportion of specific fixed costs (social infrastructure, surplus labor and equipment, for example), reducing output resulted in an increase in the average cost of production, and thus price. Firms found it difficult to find buyers at the designated price (cost plus profit markup), but could neither lower price nor declare bankruptcy (shut down). Consequently, firms turned to barter transactions, it is argued, to avoid the designated price and corresponding tax obligation.
} 


\section{William Davidson Institute Working Paper 465}

and Kleiner 1999, Rodionov 1999, Shcherbakov and Chernavskii 1998, Woodruff 1999). ${ }^{29}$ None of the studies unambiguously support either choice or circumstance. Moreover, recent studies combine the two explanations, arguing that while economic disorganization and liquidity constraints (circumstance) may have initiated the practice of barter transactions, continued and extensive use of barter transactions can only be explained by choice (Carlin et al 2000, Guriev and Kvassov 2001). ${ }^{30}$ A survey of 264 Russian firms conducted in Moscow, Rostov, Taganrog and Vladivostok in summer 2001 provide data to evaluate this proposition (see Appendix A for description of participating firms). To enhance comparability with the analysis conducted in the Section 2, however, the results presented here will focus on the responses of the seventy-nine manufacturing firms which participated in the survey.

\section{Barter Transactions: Survey Results}

Nearly half of the manufacturing firms participating in the 2001 survey reported engaging in barter transactions. The incidence varied by industry: more than two-thirds of the firms in heavy industry reported engaging in barter transactions compared to only 25 percent of the light industry firms. Seven of the eleven

${ }^{29}$ Barter transactions are not new to enterprise managers in Russia's transition economy. Above-plan production in the Soviet economy frequently traded between firms in barter arrangements (Berliner 1957 1976, Gregory and Stuart 1986). Moreover, persistent and pervasive shortages in the Soviet economy required the establishment of barter trade between firms (horizontal linkages) to obtain the requisite materials that the planning authorities (vertical linkages) failed to deliver. Makarov and Kleiner (1996) estimate that 2-6\% of the transactions between firms prior to perestroika were barter transactions established by the firms themselves in order to smooth out plan fulfillment. In many instances, local party officials acted as a clearinghouse for barter transactions, thereby reducing the time and energy required to establish a "double coincidence of wants." Nesterovich (2000) estimates that between 1985 and 1990 , the acute scarcity of goods and materials generated during perestroika increased barter transactions to at least $35 \%$ of all sales.

${ }^{30}$ Hendley et al (1997) argue that barter transactions enable firms to evade taxes. If firms inflate the barter price, driving up the cost of obtaining inputs, their profits and thus their tax obligation is reduced. To the extent that taxes are based on revenues, the seller would be unlikely to agree to such an arrangement, and the deal would be concluded only if the firms held unequal bargaining power. Barter transactions may facilitate tax evasion to the extent that barter enables firms to avoid the banking system. Banks act as an intermediary for tax collection - money deposited in the firm's bank account is automatically reduced by the amount of the firm's tax obligations. Without banks, barter transactions (trading goods for goods) may incur less risk than cash as a means of payment - handling large sums of money carries with it a very real element of danger in Russia. Finally, barter transactions (tax offsets) enable firms to evade their tax obligations - over-value goods in exchange for tax payment, with side payment to tax authority who signs off on the over-valuation. 


\section{William Davidson Institute Working Paper 465}

responding firms in construction materials reported conducting barter trades, as did ten of the nineteen food processing firms.

The manufacturing firms participating in this survey estimated that on average barter accounted for nearly $20 \%$ of their total transactions. However, the percent of barter in total transactions also varied by industry. Machine building and other heavy industry firms, on average, report about 30 percent of their total transactions involve barter. For consumer goods, food processing and construction materials, the average percentage is less than 20 percent.

Managers who reported engaging in barter transactions in 2001were asked to compare barter prices with cash prices. Contrary to arguments presented in the literature where barter prices are hypothesized as being higher than cash prices in order to reduce the firm's profitability and thereby reduce the firm's tax burden, few firms participating in this survey paid or received higher prices for goods involved in barter transactions. ${ }^{31}$ The majority (54\%) responded that barter prices were the same as cash prices; $40 \%$ reported paying or receiving lower barter prices. On average, barter prices were $6 \%$ lower than cash prices among the manufacturing firms participating in this survey.

When asked to give examples of barter transactions, managers most often described trading their final product to firms supplying them with raw materials. ${ }^{32}$ An ongoing "double coincidence of wants" may account for the slightly higher incidence of barter transactions among the construction materials and food

31 Only $5 \%$ of the manufacturing firms and $10 \%$ of the non-manufacturing firms that engaged in barter transactions and who responded to this question $(n=35, n=40$, respectively) reported barter prices higher than cash prices.

${ }^{32}$ Firms producing items used in residential and non-residential construction traded their production to firms supplying them with raw materials (timber, metals), as well as with firms which produced wood-working or other machinery. Food processing firms describe trading oil for sunflower seed, for example. Barter trade with suppliers was not limited to food processing and construction materials, however. Firms producing packaging materials traded their plastic and cardboard products to firms supplying them with raw materials. An aviation company trades technical services for spare parts; stevedores take payment in consumer goods or construction materials from the containers they loaded or unloaded. 


\section{William Davidson Institute Working Paper 465}

processing firms participating in this survey - more than half engaged in barter transactions ${ }^{33}-$ but the average share of barter trade was no higher among construction materials or food processing firms than the other manufacturing firms participating in the survey. ${ }^{34}$ For firms participating in this survey, barter transactions were used when cash transactions were not an option. Managers did not view barter transactions as a choice that they made pursuant to some strategy to sustain their network capital. Indeed, a signific ant number of firms participating in this project reported utilizing new suppliers and/or selling to new buyers in 2001 in comparison to 1990 and 1998.

Enterprise managers were asked an open-ended question about the main reasons for Russian firms to engage in barter deals. Nearly $60 \%$ of the first reasons offered involved lack of cash; less than $15 \%$ of the first reasons offered involved higher profits (lower prices) or tax avoidance. ${ }^{35}$ By way of comparison, twenty of the twenty-six manufacturing firms responding in 1999 to a question which asked about the causes of barter transactions selected "lack of cash payments from buyers" as the primary reason for barter transactions. ${ }^{36}$ Tax avoidance dominated the second reason offered in summer 2001 as an explanation for barter transactions by Russian firms: that is, $43 \%$ of the firms offering a second explanation described how barter transactions reduced or replaced cash tax payments. In most instances, however, respondents were

\footnotetext{
$3353 \%$ of the food processing firms and $60 \%$ of the construction materials firms reported engaging in barter transactions.

${ }^{34}$ Within the past year, barter trade accounted for an average of $18 \%$ of the total transactions among the food processing firms and an average of $17 \%$ of the total transactions among the construction materials firms, compared to $19 \%$ for the other manufacturing firms participating in the survey. While none of the food processing firms participating in the survey reported barter transactions exceeding $25 \%$, construction materials firms reported up to $40 \%$ of their transactions involved barter trades.

${ }^{35}$ The response patterns of the manufacturing firms compared to the non-manufacturing firms participating in the survey are different only in terms of relative magnitude: (1) both identified lack of cash as the main reason for barter transactions more often than any other explanation (59\% and 46\%, respectively), (2) both had higher profits (lower prices) and tax avoidance as the next most often cited cause of barter, but $23 \%$ of the non-manufacturing firms in comparison to $13 \%$ of the manufacturing firms described higher profits/lower prices, while an equal percentage $(\sim 12 \%)$ cited tax avoidance.

${ }^{36}$ The question asked respondents to select the relative importance in explaining barter transactions of the following 3 options: buyers/firms have no money, avoid tax payments, obtain goods to get cash for wage payments.
} 


\section{William Davidson Institute Working Paper 465}

describing tax offsets (zachety) rather than a transaction which involved trading goods for goods as a mechanism to lower their tax burden.

In-depth interviews conducted with several managers in summer 2001 reveal not only a lower reliance on barter in 2001 in comparison to previous years, but also less complicated barter trades. Previously, descriptions of barter transactions involved multiple firms, and frequently, at least two of the firms involved in the barter chain were unrelated in any production sense to either the original buying and/or selling firms. For example, barter trades by firms producing steel pipes or large capacity boilers would include transactions in the barter chain which would enable the pipe or boiler firm to acquire goods that could be sold for cash or used to pay workers (Linz 2000a, 2000b). This past summer, however, unilateral trades (a swap of materials for final product) were the norm among the barter trades described by the firms participating in this survey.

At the end of the interview, managers were asked to respond to a generic question about the incidence of barter transactions among Russian firms. That is, managers were asked for their opinion about possible changes in the incidence of barter transactions among Russian firms over the course of the current year. ${ }^{37}$ More than 8 -in-10 (84\%) anticipated no change in the incidence of barter transactions; the remainder expected barter transactions to decline over the course of $2001 .^{38}$

Barter and Firm Liquidity

Do barter transactions vary with the liquidity position of the firm? In our analysis, one dependent

\footnotetext{
${ }^{37}$ Respondents were asked: In your view, what will happen to the number of barter deals between firms in Russia this year; will barter trades increase remain the same decrease

${ }^{38}$ In an effort to check the consistency of responses related to barter trades, managers of non-manufacturing firms were asked to identify the percent of their transactions with suppliers that involved each of the following: (1) money now, product later; (2) product now, money later; (3) money now, product now; and (4) product now traded for product now or later. Of those responding, $70 \%$ of the transactions were reported as requiring money payment (an average of 54\%) in advance of receiving the product (this coincides with the response patterns to a separate set of questions about prepayment); $19 \%$ reported that between 5\% and 30\% of their transactions involved barter (product for product). This response pattern does coincide with a lower incidence of barter trades conducted by the nonmanufacturing firms participating in this survey.
} 


\section{William Davidson Institute Working Paper 465}

variable focuses on whether or not the firm engages in barter trade $;{ }^{39}$ a second focuses on the percentage of barter in total transactions. ${ }^{40}$

Several questions in the survey instrument addressed the liquidity position of the firm: whether the firm earned profits in the current or previous year (82\% said yes), whether the firm borrowed money in the past two years to cover operating expenses or to pay wages (22\% reported borrowing to finance working capital, $10 \%$ borrowed to finance wage payments), whether the firm borrowed from the bank in the past two years (10\% said yes), whether the firm borrowed from private individuals or other business organizations in the past two years (26\% said yes), whether the firm faces prepayment obligations ( $73 \%$ said yes), whether the firm sees its current financial position as improving (35\% said yes), ${ }^{41}$ and whether the firm selects “firm's lack of money" or "customers' lack of money" as the main obstacle to doing business (97\% and 95\%, respectively). ${ }^{42}$ In addition to these liquidity variables, we hypothesize that liquidity is highly correlated with particular industries. That is, while manufacturing firms tend to sell the majority of their output to wholesalers or retailers rather than to final consumers, ${ }^{43}$ industries that are closest to the cash sales of final consumers (food processing, construction materials, consumer goods/light industry, for example) are less likely to face liquidity constraints than machine building firms which sell their product to other firms. Consequently, we hypothesize that while the incidence of barter among firms in industries that are close to

\footnotetext{
${ }^{39}$ Respondents were asked: Does your firm arrange or participate in barter deals? ___ yes ___ no

${ }^{40}$ Respondents were asked: If yes, what percent of your total transactions involved barter?

${ }^{41}$ Respondents were asked: Compared to last year, how will the financial position of your firm change this year? improve remain same worsen

${ }^{42}$ Respondents were asked: What is the main obstacle to the successful operation of your firm? ___firm lacks money ____ tax system ___customers lack money ____ criminal situation / crime ____ other

${ }^{43}$ Prior to 1992, it was common for manufacturing firms to have a retail shop on their premises which sold the company's products directly to consumers. This practice has not been entirely disbanded, but with the growing multitude of well-stocked retail shops, consumers no longer need to travel to the company to purchase its product.
} 


\section{William Davidson Institute Working Paper 465}

final consumers (cash sales) may not necessarily be significantly lower, ${ }^{44}$ the volume of barter transactions by firms in these industries will be lower.

We first analyze the incidence of barter transactions among manufacturing firms participating in the survey, hypothesizing that the incidence of barter is inversely related to the firm's liquidity position. In the first specification, whether or not the firm borrowed to be able to pay wages is used as a proxy for the firm's liquidity position. Since firms can use trade credits or other non-monetary instruments to pay suppliers, one measure of the cash position of the firm is whether it must borrow money to pay wages. OLS regression results indicate that firms which borrowed money to pay wages were significantly more likely to engage in barter transactions. Conversely, we hypothesized that firms which were able to pay above-average wages would be less likely to engage in barter. OLS regression results substantiate this proposition: wages and barter are inversely related.

In the second specification, the firm's report on its financial position is used as a proxy for liquidity. We expect that the incidence of barter will be lower among firms reporting an improving financial position, as well as among firms reporting profits. Given the coding of the financial position variable $(1=$ better, $2=$ same, $3=$ worse), we expect a positive coefficient. On the profit variable (where $1=$ yes, earned profit), we expect a negative coefficient. Financial position fares better than profit in explaining the incidence of barter among the manufacturing firms participating in this survey. The coefficient on financial position has the expected sign and is significant at the $5 \%$ level; the profit coefficient is not significant.

\footnotetext{
${ }^{44}$ Firms in industries producing goods for final consumers will have a relatively easy time establishing a "double coincidence of wants" with their suppliers. A swap of final goods for production materials enables producing firms to conserve their cash, and may enable supplying firms to obtain a marketable product at a discounted price.
} 


\section{William Davidson Institute Working Paper 465}

In the third specification, the prepayment requirement is used as a proxy for the liquidity position of the firm. We hypothesize that firms which face prepayment requirements are more likely to engage in barter. If prepayment requires cash, this reduces the firm's liquidity, causing the firm to engage in barter. Alternatively, barter trade may be used to satisfy the prepayment requirement (if the firm faces a cash constraint). OLS regression results substantiate the proposition that prepayment and barter are directly related: the prepayment coefficient is positive and significant.

The three different measures we used to capture the firm's liquidity position all generate the same outcome with regard to barter: firms with less access to cash are more likely to engage in barter transactions. Additional support for this finding that barter is more likely when cash constraints are encountered is found when industry is used as a proxy for liquidity. That is, when the percent of barter transactions is used as the dependent variable in a univariate regression with a dummy variable that equals 1 for firms in heavy industry, the results indicate that, ceteris paribus, heavy industry firms (machine building firms, for example) engage in a significantly higher volume of barter transactions than the other firms participating in this survey. ${ }^{45}$

In contrast to the "virtual economy" hypothesis, our results point unambiguously to the role of liquidity in explaining both the incidence and volume of barter transactions. We find no support for the proposition that barter transactions are used to avoid restructuring. Instead, we find managers using barter to obtain necessary materials, trading their final product for these inputs. It is not the case, however, that these barter trades are exclusively with suppliers from the Soviet era; that is, managers are not relying on network capital established in the Soviet economy to maintain current operations.

\footnotetext{
${ }^{45}$ With 69 observations used in the regression, the coefficient on the industry dummy variable is .1245, with a tstatistic of 3.02 , significant at the $1 \%$ level.
} 


\section{William Davidson Institute Working Paper 465}

In contrast to the "virtual economy" hypothesis, our research results, like those documented by the monthly IET surveys, indicate that both the incidence and volume of barter transactions have declined significantly since 1998. Managers were reluctant to spend time talking about barter transactions in 2001; in their view, barter comprised a very small component of their overall operations. Managers were much more willing to talk about the restructuring activities currently taking place at their firm, as well as their plans for the future.

\section{Evidence of Enterprise Restructuring}

An extensive literature provides a multitude of quantitative and qualitative measures of enterprise restructuring in Russia and other transition economies. ${ }^{46}$ Confusion surrounding the nature and scope of active restructuring activities by Russian manufacturing firms appears to stem from: (1) the lack of clear consensus about what constitutes enterprise restructuring in transition economies and how it varies with the stage of the transition process; (2) errant assumptions about managers' objective functions; (3) the relative mix of formal and informal restructuring mechanisms; (4) the lack of attention to industry variation and, within industry, to managerial characteristics; and (5) the Texan complex (if it ain't big, it ain't ...) which causes analysts to ignore changes in enterprise operations unless they occur on a grandiose scale. In light of the volume of empirical evidence provided on an ongoing basis by reputable western and Russian scholars alike, however, we are hard pressed to explain how statements regarding the lack of enterprise restructuring in Russia repeatedly find their way into the literature.

\footnotetext{
${ }^{46}$ Empirical analyses of enterprise restructuring tend to focus on the impact of privatization on various performance indicators: change in volume or assortment of production (Earle and Telegdy 1998, Estrin and Rosevear 1999, Jones 1998, Linz 1997, Linz and Krueger 1998) and/or employment (Bilsen and Konings 1998, Linz 2001), volume of domestic and foreign sales (Buck et al 1999), and profitability (Duflo and Senik-Leygonie 1997). Numerous studies focus on the nature of the ownership structure: insiders versus outsiders, blockholders, foreign investors (Aghion and Blanchard 1996, Aghion and Carlin 1996, Anderson et al 1997), as well as managerial turnover (Barberis et al 1996, Claessens and Djankov 1999, Frydman et al 1998, Linz 1996, Roland and Sekkat 2000) and mechanisms used to select managers. A few studies focus on the extent to which competition has an effect on improving enterprise performance (Brown and Brown 1998, Earle and Estrin 1998, Brown and Earle 2000).
} 


\section{William Davidson Institute Working Paper 465}

\section{Summary and Conclusions}

We use macro-level and micro-level data to document the link between liquidity and barter in Russian industry. In doing so, we demonstrate that neither the assumptions nor the outcomes associated with the "virtual economy" interpretation of Russia are grounded in reality. Rather, the issue we identify is the low level of liquidity in Russia's economy, which needs far more attention from analysts. Low liquidity levels in Russia are the direct consequence of unreliable contract and legal enforcement which works directly to reduce the supply of credit in the economy. As we identified in a previous paper (Linz and Krueger 1998), we see this problem as the challenge for Russia's economy in its efforts to achieve normalcy.

What is to be done? If, as Millar (2001) argues, "the transition proper is over ... what we are viewing ... in the former Soviet Union is 'normal' economic, political, and social change" (p. 2), perhaps it is time to reconsider the underlying premise in the restructuring literature that "winners" are firms which mimic their capitalist counterparts, and since little evidence is apparent that Russian firms engage in comparable behavior, they are all "losers." If the transition is over, and Russia has "gotten stuck half way to a normal functioning economy" (Millar 2001, p. 4), the task before us is to construct research questions and design research projects which incorporate this reality. Like Alice, when confronted with Wonderland, we need to extend our analysis of Russia's current economic conditions to include viable options, such as the role of barter transactions in facilitating the restructuring process, ${ }^{47}$ rather than to summarily disregard these options.

\footnotetext{
${ }^{47}$ Makarov and Kleiner (2000) explain why barter transactions may extend beyond the transition period in Russia.
} 
Table 1: Share of Production Sold for Barter and Cash, 1996-2001

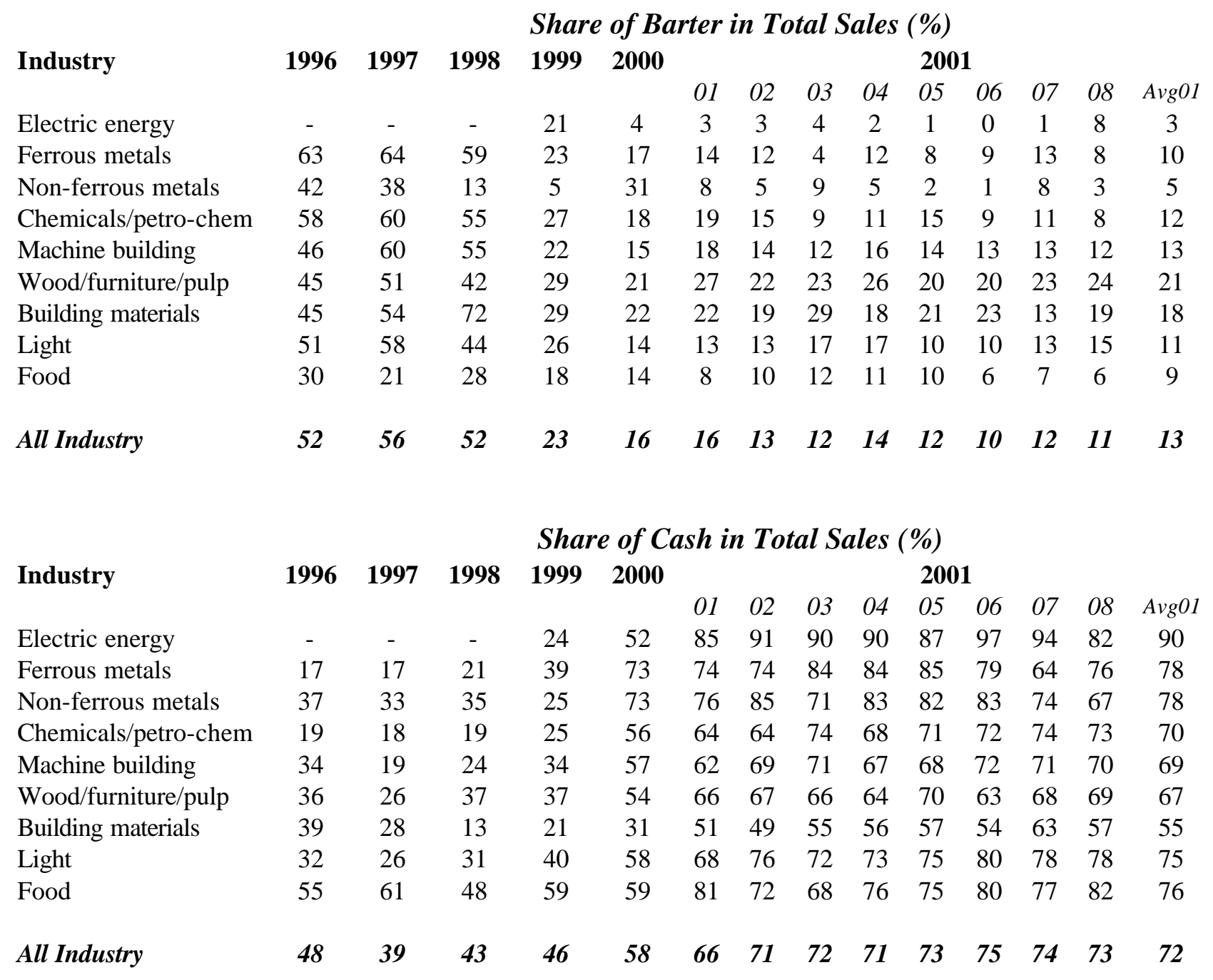

\begin{tabular}{|c|c|c|c|c|c|c|c|c|c|c|c|c|c|c|}
\hline \multirow{3}{*}{ Industry } & \multicolumn{14}{|c|}{ Share of “Other Financing” in Total Sales (\%)* } \\
\hline & \multirow[t]{2}{*}{1996} & \multirow[t]{2}{*}{1997} & \multirow[t]{2}{*}{1998} & \multirow{2}{*}{1999} & \multirow[t]{2}{*}{2000} & \multicolumn{9}{|c|}{2001} \\
\hline & & & & & & 01 & 02 & 03 & 04 & 05 & 06 & 07 & 08 & AvgOl \\
\hline Electric energy & - & - & - & 55 & 44 & 12 & 6 & 6 & 8 & 12 & 3 & 5 & 10 & 8 \\
\hline Ferrous metals & 20 & 19 & 39 & 68 & 10 & 12 & 14 & 12 & 4 & 7 & 12 & 23 & 16 & 11 \\
\hline Non-ferrous metals & 21 & 21 & 52 & 70 & 104 & 16 & 10 & 20 & 12 & 16 & 16 & 18 & 30 & 17 \\
\hline Chemicals/petro-chem & 33 & 22 & 26 & 48 & 26 & 17 & 21 & 17 & 21 & 14 & 19 & 15 & 19 & 18 \\
\hline Machine building & 20 & 21 & 21 & 44 & 28 & 20 & 17 & 17 & 16 & 18 & 15 & 16 & 18 & 17 \\
\hline Wood/furniture/pulp & 19 & 23 & 21 & 34 & 25 & 7 & 11 & 11 & 10 & 10 & 17 & 9 & 7 & 10 \\
\hline Building materials & 16 & 18 & 15 & 50 & 47 & 27 & 32 & 16 & 26 & 22 & 23 & 23 & 23 & 24 \\
\hline Light & 17 & 16 & 25 & 44 & 28 & 19 & 11 & 11 & 10 & 15 & 10 & 9 & 7 & 12 \\
\hline Food & 15 & 18 & 24 & 23 & 27 & 11 & 18 & 20 & 13 & 15 & 14 & 16 & 12 & 15 \\
\hline All Industry & 0 & 5 & 5 & 31 & 26 & 18 & 16 & 16 & 15 & 15 & 15 & 14 & 16 & 16 \\
\hline
\end{tabular}

${ }^{*}$ Calculated by summing barter and cash sales, and subtracting the sum from 100 percent.

Source: IET, Russian Industrial Trends Surveys, October 2000, March 2001, June 2001, September 2001. 
William Davidson Institute Working Paper 465

Table 2: Avoid Non-Monetary Transactions

Would your firm like to avoid non-monetary transactions?

\section{Percent responding YES}

$10 / 1999 \quad 5 / 2000 \quad 10 / 2000$

\section{Industry}

Electric energy

Ferrous metals

Non-ferrous metals

Chemicals/petro-chemicals

Engineering

Wood/furniture/pulp

Building materials

Light

Food

$$
\mathrm{N}=
$$

96

91

64

93

92

84

92

90

86

100
83
93
77
96
89
85
90
80

100
100
84
87
87
78
93
88
75

1028

n.a.

1007
Could your firm avoid non-monetary transactions?

Percent responding YES

$10 / 19995 / 2000 \quad 10 / 2000$

Source: Institute for the Economy in Transition (October 2000). 


\section{Table 3: Trends in Barter Transactions, 1999-2001}

What has been the trend over the past 2-3 months of the volume of barter transactions?

1999

March
May
June
July
Augu
Septem
Octo
Nove
Decem
$\mathbf{2 0 0 0}$

February $\quad(\mathrm{n}=1052)$

April $\quad(n=1037)$

May $\quad(n=1047)$

June $\quad(n=1039)$

July $\quad(n=1009)$

August $(n=999)$

September $(\mathrm{n}=\mathrm{n} / \mathrm{a})$

October $(n=1003)$

November $(n=1007)$

December $(n=996)$

2001

January $(n=1045)$

February $(\mathrm{n}=1000)$

$\operatorname{March}(\mathrm{n}=902)$

April $(\mathrm{n}=1001)$

May $(n=1009)$

June $(\mathrm{n}=\mathrm{n} / \mathrm{a})$

July $(\mathrm{n}=989)$

August $(\mathrm{n}=970)$

September $(\mathrm{n}=959)$

October $(\mathrm{n}=962)$

\section{Up Same Down N/A \\ (Percent responding)}

$\begin{array}{llll}12 & 65 & 13 & 10\end{array}$

$\begin{array}{llll}13 & 57 & 20 & 20\end{array}$

$\begin{array}{llll}8 & 65 & 18 & 9\end{array}$

$\begin{array}{llll}8 & 62 & 20 & 10\end{array}$

$\begin{array}{llll}7 & 55 & 28 & 10\end{array}$

$\begin{array}{llll}5 & 71 & 17 & 7\end{array}$

$\begin{array}{llll}8 & 60 & 22 & 10\end{array}$

$\begin{array}{llll}9 & 60 & 22 & 9\end{array}$

$\begin{array}{llll}7 & 65 & 16 & 12\end{array}$

$\begin{array}{llll}7 & 60 & 19 & 11\end{array}$

Up Same Down N/A

(Percent responding)

\begin{tabular}{rrrr}
7 & 63 & 19 & 11 \\
6 & 57 & 22 & 15 \\
6 & 60 & 19 & 15 \\
3 & 61 & 24 & 12 \\
6 & 59 & 24 & 11 \\
4 & 54 & 29 & 13 \\
5 & 53 & 27 & 15 \\
4 & 53 & 28 & 15 \\
2 & 57 & 26 & 15 \\
2 & 61 & 22 & 15 \\
& \multicolumn{4}{c}{ Same Down } & N/A \\
Up & (Percent responding)
\end{tabular}

(Percent responding)

$\begin{array}{ccccc} & 4 & 54 & 23 & 19 \\ & 6 & 52 & 19 & 23 \\ & 4 & 58 & 18 & 20 \\ 5 & 54 & 17 & 23 & \\ & 58 & 20 & 17 & \\ & 6 & 51 & 20 & 23 \\ & 5 & 57 & 17 & 21 \\ & 4 & 58 & 18 & 20 \\ & 2 & 59 & 18 & 21 \\ & 2 & 63 & 16 & 19\end{array}$

What is the expected trend for the next 2-3 months in volume of barter transactions? Up $\underset{\text { (Percent responding) }}{\text { Same Down N/A }}$

$\begin{array}{rlll}17 & 61 & 11 & 11 \\ 14 & 59 & 13 & 14 \\ 9 & 58 & 21 & 12 \\ 8 & 65 & 14 & 13 \\ 7 & 58 & 17 & 16 \\ 8 & 65 & 17 & 10 \\ 11 & 61 & 18 & 10 \\ 10 & 65 & 14 & 11 \\ 10 & 58 & 18 & 14 \\ 6 & 61 & 17 & 16\end{array}$

Up Same Down N/A (Percent responding)

$\begin{array}{llll}7 & 64 & 15 & 14 \\ 6 & 60 & 17 & 17 \\ 7 & 59 & 17 & 17 \\ 6 & 62 & 19 & 13 \\ 5 & 60 & 18 & 17 \\ 5 & 51 & 31 & 13 \\ 5 & 50 & 13 & 25 \\ 5 & 53 & 24 & 19 \\ 4 & 59 & 21 & 16 \\ 4 & 57 & 23 & 16\end{array}$

Up Same Down N/A (Percent responding)

$\begin{array}{ccccc} & 6 & 55 & 12 & 27 \\ & 5 & 61 & 11 & 23 \\ & 5 & 60 & 12 & 23 \\ 5 & 54 & 13 & 38 & \\ & 62 & 15 & 18 & \\ & 29 & 44 & 17 & 10 \\ & 4 & 57 & 12 & 27 \\ & 6 & 60 & 14 & 20 \\ & 3 & 60 & 13 & 24 \\ & 3 & 54 & 14 & 29\end{array}$

Source: Institute for the Economy in Transition 


\title{
William Davidson Institute Working Paper 465
}

\author{
Appendix A: \\ Sample Description
}

A total of 264 Russian firms participated in a survey conducted in Moscow, Rostov ${ }^{48}$ and Vladivostok in spring and summer 2001. The project focused on a series of topics related to current business conditions in Russia, with particular attention to barriers to investment. Local project coordinators contacted companies and arranged to interview the owner, executive director, or his/her representative. ${ }^{49}$ Sample selection procedures were guided by the directive to local project coordinators to include as wide a variety as possible among the participating firms in each location. ${ }^{50}$ Top-level managers or owners responded to more than 40 questions related to the operation and performance of their company. Among the 264 participating firms, $46 \%$ were retail shops, $30 \%$ were manufacturing plants, and $24 \%$ were "other" (non-retail) service sector firms. ${ }^{51}$

Workforce size varied significantly by type of firm: retail shops employed, on average, 43 workers; manufacturing plants employed 373 workers, on average; and other service sector firms employed 78 workers. Average wages also varied by type of firm, with retail shops paying, on average, 3108 rubles per month; manufacturing firms paying 2010 rubles per month, and other service sector firms paying an average of 1977 rubles per month. Equally striking is the regional wage variation. Among retail shops, where the skills required for employment are approximately the same regardless of region, average monthly wages were reported at 5213 in Moscow, 4007 in Vladivostok, 2010 in Rostov, and 1440 in Taganrog ( $100 \mathrm{~km}$ from Rostov).

The majority of firms (62\%) reported their ownership structure as limited liability; 22\% reported their ownership structure as joint stock, of which more than two-thirds were "closed." Just over $10 \%$ of the firms were privately-owned; $2 \%$ were owned by municipal organizations. The 264 participating firms were nearly equally split between leasing and owning the facilities in which their company operated: $51 \%$ reported that they leased the buildings; $49 \%$ reported owning. Not surprisingly given regional price differentials, the relative share of firms leasing their facilities was higher in Moscow (95\%) and Vladivostok (72\%) than among firms in the Rostov region. ${ }^{52}$

${ }^{48}$ Of the firms located in Rostov region, 136 were located in Taganrog, 35 in Rostov, and 3 in Azov.

${ }^{49}$ In some instances it was possible to have a bookkeeper provide information for 2-3 firms; that is, if one person kept the books for multiple firms, this person was asked to participate in multiple interview sessions (one for each firm).

${ }^{50}$ I thank Michael Morozov, Inna Petrova, and Larissa Chouripa for their assistance with the data collection involved in this project.

${ }^{51}$ Although separate questionnaires were developed to take into account differences associated with the operation and performance of the three types of firms (retail, manufacturing, services), a core set of 32 questions was included in all versions.

${ }^{52}$ In Taganrog, $70 \%$ of the firms reported owning the building(s) in which their company operated. 


\section{William Davidson Institute Working Paper 465}

\section{Retail Shops}

Owners or top-level managers of 122 retail shops participated in the interview project. Of these, 40 were located in Moscow, 52 in Taganrog, 10 in Rostov, and 20 in Vladivostok. The participating firms employed, on average, 43 workers, and operated, on average, in 4 locations. ${ }^{53}$ The retail shops participating in this survey included 30 firms reporting sales dominated by food items, 40 firms reporting sales dominated by alcohol, tobacco products and candy, and 26 firms selling various consumer goods (clothing, video equipment, cosmetics, household items and souvenirs, for example).

The retail shop respondents were asked whether the company earned a profit in the first year of operations: $84 \%$ responded affirmatively. When asked about the percent of profit re-invested in the firm, the responses ranged from $2 \%$ to $100 \%$, with a mean of $42 \%$. When asked how their current financial position compares with the previous year, responses were equally split between "better" and "the same." There was significant regional variation in the response patterns: retail shops in Moscow and Vladivostok were much less likely to say "better" than their counterparts in Rostov and Taganrog.

To capture changes in consumer preferences,${ }^{54}$ respondents were asked about the percent of the shop's current merchandise that was made in Russia, and how that figure compares to 1998. Retail shops report that, on average, $68 \%$ of their current merchandise was made in Russia, and $77 \%$ of the retail shops report that the proportion of Russian-made goods nowadays is greater (higher) than what the shop offered in 1998. There was no significant variation in response patterns by region with regard to these results.

The retail shops participating in this study were in agreement about what needs to be done to improve economic and business conditions in Russia: reduce taxes, improve the laws and legal system, and stabilize the economy at a level of operation that generates a higher income for the average worker.

\section{Manufacturing Firms}

Of the 79 manufacturing plants participating in the project, 41 were located in Taganrog (52\%), 22 in Rostov (28\%), 2 in Azov, and 14 in Vladivostok. One-third of the firms were engaged in the production of consumer goods (light industry), employing an average of 150 workers; one-quarter were food processing plants, employing an average of 457 workers. Producers of construction materials accounted for $13 \%$ of the firms and employed an average of 286 workers; $4 \%$ of the firms produced machinery and equipment (heavy industry), employing on average 1367 workers. The majority of firms reported their ownership structure as

\footnotetext{
53 Among retail shops in Moscow, average workforce size was 28 employees; in Taganrog, 59 employees; in Rostov, 58 employees, and in Vladivostok, 10 employees. Retail shops in Moscow, on average, operated in 2 locations; in Taganrog, in 5 locations; in Rostov, in 3 locations, and in Vladivostok, in 4 locations.

${ }^{54}$ At the beginning of the transition process, various market students indicate that Russian consumers reported preferring non-Russian goods (see Huddleston and Good 1996, BISNIS October 2001). Shops were stocked almost exclusively with imported goods from 1993-1997. Since the financial crisis in August 1998, shelves appear to encompass a greater portion of Russian-made goods. This study attempted to identify the share of Russian-made products which retail shops tend to stock (sell).
} 


\section{William Davidson Institute Working Paper 465}

joint stock (46\%) or limited liability (44\%).

On average, the participating manufacturing firms paid 2010 rubles per month, with food processing firms paying 2233 rubles per month, construction materials firms paying 2230 per month, heavy industry firms paying 2100 per month, and light industry firms paying 1964 per month. Among the food processing plants, average wages were highest in Vladivostok (4375 rubles), with firms in Rostov paying 2200 rubles per month. Food processing plants in Taganrog paid an average of 1490 rubles per month.

Two-thirds of the manufacturing firms participating in this project leased the buildings in which their company operated (among food processing plants, only 11\% reported leasing their facilities). Among those reporting ownership of the buildings in which their company operated, 58\% were located in Taganrog, 27\% in Rostov, and $12 \%$ in Vladivostok.

Just over one-quarter of the participating manufacturing firms reported plans for renovating their plant during the current year. On average, these firms report needing to replace $40 \%$ of their capital stock and $13 \%$ of their workers.

\section{Other Service Sector Firms}

Many of the 63 non-retail firms participating in this survey were involved in wholesale trade or repair work. Average wages paid by these firms ranged from 1463 rubles per month in Taganrog to 4052 rubles per month in Vladivostok. These firms employed an average of 78 workers, and were equally split between owning $(50 \%)$ and leasing $(50 \%)$ the facilities in which their company operated. 
William Davidson Institute Working Paper 465

References

Aghion, Philippe and Olivier Blanchard. 1996. “On Insider Privatization,” European Economic Review vol 40, no 4 (April), pp. 759-766.

Aghion, Philippe and Wendy Carlin. 1996. "Restructuring Outcomes and the Evolution of Ownership Patterns in Central and Eastern Europe,” Economics of Transition, vol 4 no 2 (October), pp. 371-388.

Anderson, James H, Georges Korsun, and Peter Murrell. 1999. "Ownership, Exit, and Voice After Mass Privatization: Evidence from Mongolia,” Economics of Transition, vol 7 no 1 (March), pp. 215-243.

Aslund, Anders. 2001. "Think Again - Some Common Misconceptions about Russia," Transition Newsletter (World Bank/William Davidson Institute), pp. 13-15.

Aukutsionek, S. 1998. "Industrial Barter in Russia," Communist Economies and Economic Transformation, vol 10, no 2, pp. 179-188.

Barberis, Nicholas, Maxim Boycko and Andrei Shliefer. 1996. "How Does Privatization Work? Evidence from the Russian Shops,” Journal of Political Economy, vol 104, no 4 (August), pp. 764-790.

Berliner, Joseph S. 1976. The Innovation Decision in Soviet Industry (Cambridge MA: MIT Press).

Bilsen, Valentijn and Jozef Konings. 1998. "Job Creation, Job Destruction, and Growth of Newly Established, Privatized and State-Owned Enterprises in Transition Economies: Survey Evidence from Bulgaria, Hungary, and Romania," Journal of Comparative Economies, vol 26, no 3 (September), pp. 429445 .

Blasi, Joseph et al. 1997. Kremlin Kapitalism: Privatizing the Russian Economy (Ithaca NY: Cornell University Press).

Brana, Sophie and Mathilde Maurel. 2000. "Le Troc en Russie: Un Probleme de Liquidite ou de Solvabilite? (Barter in Russia: A Matter of Liquidity or a Matter of Solvency?) Revue Economique, vol 51, no 3 (May), pp. 659-669.

Broadman, Harry G. 2000. "Reducing Structural Dominance and Entry Barriers in Russian Industry," Review of Industrial Organization, vol 17, no 2 (September), pp. 155-176.

Brown, J. David and John S. Earle. 2001. "Privatization, Competition, and Reform Strategies: Theory and Evidence from Russian Enterprise Panel Data," unpublished manuscript, SITE (February).

Carlin, Wendy and Philippe Aghion. 1996. "Restructuring Outcomes and the Evolution of Ownership Patterns in Central and Eastern Europe," Economics of Transition, vol 4, no 2 (October), pp. 371-388. 


\section{William Davidson Institute Working Paper 465}

Carlin, Wendy, Steven Fries, Mark Schaffer and Paul Seabright. 2000. "Barter and Non-Monetary Transactions in Transition Economies: Evidence from a Cross-Country Survey,” EBRD Working Paper no 50 (June).

Claessens, Stijn and Simeon Djankov. 1999. "Enterprise Performance and Management Turnover in the Czech Republic," European Economic Review, vol 43, no 4-6 (April), pp. 1115-1124.

Commander, Simon and Christian Mumssen. 1998. "Understanding Barter in Russia," EBRD Working Paper no 37 (December).

Desai, Padma and Todd Idson. 2000. Work Without Wages: Russia's Nonpayment Crisis (Cambridge: MIT Press).

Desai, Raj and Itzahk Goldberg. 2000. "Stakeholders, Governance, and the Russian Enterprise Dilemma," Finance and Development, vol 37, no 2 (June), pp. 14-18.

Djanko, Simeon and Peter Murrell. 2000. "Enterprise Restructuring in Transition: A Quantitative Survey," unpublished manuscript, World Bank/University of Maryland (April).

Duflo, Esther and Claudia Senik-Leygonie. 1997. "Industrial Restructuring in Russia: Early Reactions of Firms to the Shock of Liberalization," Economics of Transition, vol 5, no 1 (May), pp. 45-62.

Dyker, David A. 2000. "The Structural Origins of the Russian Economic Crisis," Post-Communist Economies, vol 12, no 1 (March), pp. 5-24.

Earle, John and Almos Telegdy. 1998. "The Results of Mass Privatization in Romania: A First Empirical Study," Economics of Transition, vol 6 no 2 (November), pp. 313-332.

Ericson, Richard E. 1996. "Restructuring Industry During Transition: A Two Period Model," Columbia University, Department of Economics Working Paper, no 9697-03 (September).

Ericson, Richard E. 1999. "The Structural Barrier to Transition Hidden in Input-Output Tables of Centrally Planned Economies," Economic Systems, vol 23, no 3 (September), pp. 199-224.

Estrin, Saul and Adam Rosevear. 1999. "Enterprise Performance and Corporate Governance in Ukraine," Journal of Comparative Economics, vol 27, no 3 (September), pp. 442-458.

Filatotchev, Igor, Mike Wright and Michael Bleaney. 1999. "Privatization, Insider Control and Managerial Entrenchment in Russia," Economics of Transition, vol 7, no 2 (October), pp. 481-504.

Frydman, Roman, Marek Hessel and Andrej Rapaczynski. 1998. "Why Ownership Matters: Entrepreneurship and the Restructuring of Enterprises in Central Europe," New York University Working Paper (August). 


\section{William Davidson Institute Working Paper 465}

Gaddy, Clifford and Barry W. Ickes. 1998a. "To Restructure or Not to Restructure: Informal Activities and Enterprise Behavior in Transition," unpublished manuscript, The Brookings Institution and Pennsylvania State University (May).

Gaddy, Clifford and Barry W. Ickes. 1998b. “Russia’s Virtual Economy,” Foreign Affairs (SeptemberOctober), pp. 53-67.

Gaddy, Clifford and Barry W. Ickes. 1999. "An Accounting Model of the Virtual Economy in Russia," Post-Soviet Geography and Economics, vol 40, no 2 (March), pp. 79-97.

Gonchar, Ksenia and Herbert Wulf. 1998. "Lessons Learned from Conversion in Russia and Western Europe," Defence and Peace Economics vol 9 no 4 (Winter), pp. 339-365.

Granick, David. 1954. The Red Executive (New York: Columbia University Press).

Guriev, Sergei and Barry W. Ickes. 1999. "Barter in Russia," in Paul Seabright (ed) The Vanishing Ruble: Barter Networks and Non-Monetary Transactions in Post-Soviet Societies (New York: Cambridge University Press).

Guriev, Sergei, Igor Makarov and Mathilde Maurel. 2000. "Debt Overhang and Barter in Russia," University of Michigan, William Davidson Institute Working Paper no 339 (September).

Guriev, Sergei and Dmitry Kvassov. 2001. "Barter For Price Discrimination? A Theory and Evidence from Russia," unpublished manuscript, New Economic School, Moscow (February).

Hendley, Kathryn, et al. 1997. "Observations on the Use of Law by Russian Enterprises," Post-Soviet Affairs, vol 13, no 2 (January-March), pp. 19-41.

Hendley, Kathryn, Barry Ickes and Randi Ryterman. 1998. "Remonetizing the Russian Economy," in H.G. Broadman (ed.) Russian Enterprise Reform: Policies to Further the Transition (Washington DC: World Bank) (November).

Izyumov, Alexei, Leonid Kosals and Rosalina Ryvkina. 2000. "Defense Industry Transformation in Russia: Evidence from a Longitudinal Survey," Post-Communist Economies, vol 12, no 2 (June), pp. 215228.

Jones, Dereck C. 1998. "The Economic Effects of Privatization: Evidence from a Russian Panel," Comparative Economic Studies, vol 40 no 2 (Summer), pp. 75-102.

Krueger, Gary. 1993. "Priorities in Central Planning," Journal of Comparative Economics vol 15, no 4 (December), pp. 627-645.

Krueger, Gary. 1995. "Transition Strategies of Former State Owned Firms in Russia" Comparative Economic Systems (Winter)

Krueger, Gary. Between Two Fires: Russian Industry in Transition. in process. 


\section{William Davidson Institute Working Paper 465}

Leary, Neil and Judith Thornton. 1989. "Are Soviet Firms Innoculated against Innovation Comparative Economic Studies vol 41 no 2 (Summer), pp. 42-65.

Linz, Susan J. 1988. “Managerial Autonomy in Soviet Firms," Soviet Studies vol 40, no 2 (April), pp. 175-195.

Linz, Susan J. 1997. "Russian Firms in Transition: Champions, Challengers, and Chaff," Comparative Economic Studies vol 39, no 2 (Summer 1997), pp. 1-36.

Linz, Susan J. 2000. "Barter Transactions Among Russian Firms: You Do Get Your Dog Back," presented at AAASS meetings, Denver Colorado (November).

Linz, Susan J. 2001. "Restructuring with What Success? A Case Study of Russian Firms," Comparative Economic Studies vol 43 no 1 (Spring), pp. 75-99.

Linz, Susan J. 2001. “Ownership and Employment in Russian Industry: 1992-1995," International Journal of Manpower (forthcoming).

Linz, Susan J. and Gary Krueger. 1998. "Enterprise Restructuring in Russia's Transition Economy: Formal and Informal Mechanisms," Comparative Economic Studies, vol 40, no 2 (Summer), pp. 5-52.

Makarov V and G. Kleiner, 1996. Barter v ekonomike Rossii: osobennonosti i tendentsii perekhodnogo perioda (Barter in the Russian Economy: Specific features and Trends of the Transitional Period) Moscow: TsEMI, Russian Academy of Sciences (RAN), Working Paper \# WP96/006.

Makarov and Kleiner 2000 "Barter in Russia: An Institutional Stage," Problems of Economic Transition vol 42, no 11 (March), pp. 51-79

Marin, Dalia. 2000. "Trust versus Illusion: What is Driving Demonetization in Russia?" CEPR Working paper (September).

Millar, James R. 1999. "A Critique of the 'Virtual Economy' Concept and an Alternative Explanation of the August 1998 Russian Crash," paper presented at Symposium on The Continuing Economic Crisis in Russia: Causes, Consequences, and Prospects, George Washington University, Washington D.C. (May).

Millar, James R. 2000. “Can Putin Jump-Start Russia's Stalled Economy?” Current History, vol 99, no 639 (October), pp. 329-333.

Millar, James R. 2001. "The Post Cold War Settlement and the End of the Transition," NewsNet, Newsletter of the AAASS (January), pp. 1-5.

Moers, Luc. 2000. "Determinants of Enterprise Restructuring in Transition: Description of a Survey of Russian Industry," Post-Communist Economies, vol 12, no 3 (September), pp. 307-335.

Orlova, Natalia and Andrei Roudenko. 2001. "Cross Subsidization: Roadblock to Reform,” Alpha-Bank Research Department (Moscow: 29 June 2001). 


\section{William Davidson Institute Working Paper 465}

Pinto, Brian, Vladimir Drebentsov, and Alexander Morozov. 2000. "Give Macroeconomic Stability and Growth in Russia a Chance," Economics of Transition, vol 8, no 2, pp. 297-324.

Polonsky, Gennady and Zavan Aivazian. 2000. "Restructuring Russian Industry: Can it Really be Done?" Post-Communist Economies, vol 12, no 2 (June), pp. 229-240.

Roland, Gerard and Khalid Sekkat. 2000. "Managerial Career Concerns, Privatization and Restructuring in Transition Economies," European Economic Review.

Seabright, Paul (ed.). 2000. The Vanishing Rouble: Barter Networks and Non-Monetary Transactions in PostSoviet Societies (New York: Cambridge University Press).

Sedaitis, Judith. 2000. "Technology Transfer in Transition Economies: A Test of Market, State and Organizational Models," Research Policy vol 29 no 2 (February), pp. 135-147.

Treisman, Daniel. 2000. "Inter-enterprise Arrears and Barter in the Russian Economy," Post-Soviet Affairs, vol 16, no 3 (July-September), pp. 225-256.

Williamson, S. and R. Wright. 1995. "Barter and Monetary Exchange under Private Information," American Economic Review vol 84, pp. 104-23.

Woodruff, David. 1999. Money Unmade: Barter and the Fate of Russian Capitalism (Ithaca NY: Cornell University Press).

World Bank. 1999. “Non-Payments in Russia,” (Washington DC: World Bank mimeo).

Yakovlev, Andrei. 1998. "Barter and Clearing schemes: How to define Basic Concepts," Russian Economic Barometer, vol 7 no 2, pp. 39-44

Yakovlev, Andrei. 2000. "The Causes of Barter, Nonpayments, and Tax Evasion in the Russian Economy," Problems of Economic Transition, vol 42, no 11 (March), pp. 80-96.

Yakovlev, Andrei. 2000. "Barter in the Russian Economy: Classifications and Implications (Evidence from Case Study Analyses)," Post-Communist Economies, vol 12, no 3 (September), pp. 279-291. 


\section{DAVIDSON INSTITUTE WORKING PAPER SERIES - Most Recent Papers}

The entire Working Paper Series may be downloaded free of charge at: www.wdi.bus.umich.edu

CURRENT AS 5/7/02

\begin{tabular}{|c|c|c|}
\hline Publication & Authors & Date \\
\hline No. 465: Virtual Reality: Barter and Restructuring in Russian Industry & Gary Krueger and Susan J. Linz & Apr. 2001 \\
\hline $\begin{array}{l}\text { No. 464: Lending of Last Resort, Moral Hazard and Twin Crises: } \\
\text { Lessons from the Bulgarian Financial Crisis 1996/1997 }\end{array}$ & $\begin{array}{l}\text { Michael Berlemann, Kalin } \\
\text { Hristov and Nikolay Nenovsky }\end{array}$ & May 2002 \\
\hline $\begin{array}{l}\text { No. 463: Deindustrialisation. Lessons from the Structural Outcomes of } \\
\text { Post-Communist Transition }\end{array}$ & $\begin{array}{l}\text { Tomasz Mickiewicz and Anna } \\
\text { Zalewska }\end{array}$ & Jan. 2002 \\
\hline $\begin{array}{l}\text { No. 462: Joint Liability Lending and the Rise and Fall of China's } \\
\text { Township and Village Enterprises }\end{array}$ & Albert Park and Minggao Shen & July 2001 \\
\hline $\begin{array}{l}\text { No. 461: A Refinancing Model of Decentralization with Empirical } \\
\text { Evidence from China }\end{array}$ & Albert Park and Minggao Shen & Apr. 2002 \\
\hline $\begin{array}{l}\text { No. 460: The Effects of Market Liberalization on the Relative Earnings } \\
\text { of Chinese Women }\end{array}$ & Margaret Maurer-Fazio & Mar. 2002 \\
\hline $\begin{array}{l}\text { No. 459: The Role of Education in Determining Labor Market } \\
\text { Outcomes in Urban China's Transitional Labor Markets }\end{array}$ & Margaret Maurer-Fazio & Apr. 2002 \\
\hline $\begin{array}{l}\text { No. 458: Real and Monetary Convergence within the European Union } \\
\text { and Between the European Union and Candidate Countries: } \\
\text { A Rolling Cointegration Approach }\end{array}$ & $\begin{array}{l}\text { Josef C. Brada, Ali M. Kutan and } \\
\text { Su Zhou }\end{array}$ & Apr. 2002 \\
\hline No. 457: Credit Ratings as Coordination Mechanisms & $\begin{array}{l}\text { Arnoud W. A. Boot and Todd T. } \\
\text { Milbourn }\end{array}$ & Mar. 2002 \\
\hline $\begin{array}{l}\text { No. 456: Balkan and Mediterranean Candidates for European Union } \\
\text { Membership: The Convergence of their Monetary Policy with that of the } \\
\text { European Central Bank }\end{array}$ & Josef C. Brada and Ali M. Kutan & Apr. 2002 \\
\hline $\begin{array}{l}\text { No. 455: Russian Financial Transition: The Development of Institutions } \\
\text { and Markets for Growth }\end{array}$ & David M. Kemme & Oct. 2001 \\
\hline $\begin{array}{l}\text { No. 454: Does the Market Pay Off? Earnings Inequality and Returns to } \\
\text { Education in Urban China }\end{array}$ & Xiaogang $\mathrm{Wu}$ and $\mathrm{Yu}$ Xie & Apr. 2002 \\
\hline $\begin{array}{l}\text { No. 453: Entrepreneurs' Access to Private Equity in China: } \\
\text { The Role of Social Capital }\end{array}$ & Bat Batjargal and Mannie M. Liu & Apr. 2002 \\
\hline $\begin{array}{l}\text { No. 452: The Determinants of Privatised Enterprise Performance in } \\
\text { Russia }\end{array}$ & $\begin{array}{l}\text { Alan A. Bevan, Saul Estrin, Boris } \\
\text { Kuznetsov, Mark E. Schaffer, } \\
\text { Manuela Angelucci, Julian } \\
\text { Fennema and Giovanni } \\
\text { Mangiarotti }\end{array}$ & June 2001 \\
\hline $\begin{array}{l}\text { No. 451: Determinants of Financial Distress: What Drives Bankruptcy } \\
\text { in a Transition Economy? The Czech Republic Case }\end{array}$ & Lubomír Lízal & Jan. 2002 \\
\hline No. 450: Corporate Governance and the Global Social Void & Lee A. Tavis & Oct. 2001 \\
\hline $\begin{array}{l}\text { No. 449: Financial Architecture and Economic Performance: } \\
\text { International Evidence }\end{array}$ & Solomon Tadesse & Aug. 2001 \\
\hline $\begin{array}{l}\text { No. 448: Growth Slowdown Under Central Planning: A Model of Poor } \\
\text { Incentives }\end{array}$ & Zuzana Brixiová and Aleš Bulír & Mar. 2002 \\
\hline $\begin{array}{l}\text { No. 447: Disentangling Treatment Effects of Polish Active Labor } \\
\text { Market Policies: Evidence from Matched Samples }\end{array}$ & $\begin{array}{l}\text { Jochen Kluve, Hartmut Lehmann, } \\
\text { and Christoph M. Schmidt }\end{array}$ & Jan. 2002 \\
\hline $\begin{array}{l}\text { No. 446: The Impact of Socialist Imprinting and Search for Knowledge } \\
\text { on Resource Change: An Empirical Study of Firms in Lithuania }\end{array}$ & $\begin{array}{l}\text { Aldas Kriauciunas and Prashant } \\
\text { Kale }\end{array}$ & Mar. 2002 \\
\hline $\begin{array}{l}\text { No. 445: The Costs, Wealth Effects, and Determinants of International } \\
\text { Capital Raising: Evidence from Public Yankee Bonds }\end{array}$ & $\begin{array}{l}\text { Darius P. Miller and John J. } \\
\text { Puthenpurackal }\end{array}$ & Oct. 2001 \\
\hline No. 444: Financial Institutions, Contagious Risks, and Financial Crises & $\begin{array}{l}\text { Haizhou Huang and Chenggang } \\
\mathrm{Xu}\end{array}$ & Nov. 2001 \\
\hline No. 443: Banks as Catalysts for Industrialization & $\begin{array}{l}\text { Marco Da Rin and Thomas } \\
\text { Hellmann }\end{array}$ & Oct. 2001 \\
\hline $\begin{array}{l}\text { No. 442: Bank-Based or Market-Based Financial Systems: Which is } \\
\text { Better? }\end{array}$ & Ross Levine & Feb. 2002 \\
\hline
\end{tabular}

